Article

\title{
Social Impacts of Solar Home Systems in Rural Areas: A Case Study in Bangladesh
}

\author{
Ehsanul Kabir ${ }^{1}$, Ki-Hyun Kim ${ }^{2, *}$ (D) and Jan E. Szulejko ${ }^{2}$ \\ 1 Department of Farm Power and Machinery, Bangladesh Agricultural University, Mymensingh 2202, \\ Bangladesh; kabir408@gmail.com \\ 2 Department of Civil and Environmental Engineering, Hanyang University, 222 Wangsimni-Ro, Seoul 04763, \\ Korea; yan.shuleiko@gmail.com \\ * Correspondence: kkim61@hanyang.ac.kr; Tel.: +82-2-2220-2325; Fax: +82-2-2220-1945
}

Received: 23 August 2017; Accepted: 13 October 2017; Published: 16 October 2017

\begin{abstract}
As an alternative source of off-grid electric power, solar home systems (SHS) stand out above all other options (e.g., wind, hydro, geo-thermal, tidal systems) because of their wide-scale potential at latitudes less than $45^{\circ}$ north or south of the Equator where daily solar irradiance is more constant throughout the year and where the bulk of the Third World's population live. A questionnaire-based survey study was carried out in a rural area of Bangladesh to ascertain the impacts of SHSs on the lives of the rural population. The installation of an SHS was found to improve the comfort and living standard of rural dwellers. Easier access to TV, radio, cellphone, and the Internet helped the rural population become part of a more global culture. More attractive down-payment and installment package options will allow poor target groups to adopt this system. The standard of SHS components and after-sales service should be improved to ensure sustainably and popularity among the mass population for at least 10 years at minimal cost to the consumer. Our findings can also help policymakers adopt more SHS-friendly policies to further the interests of inhabitants of rural areas that are not connected to the grid.
\end{abstract}

Keywords: solar home systems; rural households; impacts; livelihoods

\section{Introduction}

Lack of access to electricity is a major constraint on growth and development in Third World rural areas [1]. A large number of rural settlements are still without access to electricity, especially in sub-Saharan Africa and developing Asian countries [2]. Due to high transmission and distribution costs in remote areas, many households are not connected to the national electricity network [3]. For example, in rural areas of Bangladesh, where more than $70 \%$ of the population lives, only $42 \%$ have access to the (unreliable) electricity supply [4].

Global electricity generation depends mainly on depleting fossil fuel sources followed by nuclear, hydro, and other renewable sources (e.g., wind, solar, tidal wave, and geo-thermal energy). Pollution emitted by coal and natural gas plants is linked to several types of health and environmental hazards [5,6]. Moreover, $\mathrm{CO}_{2}$ emissions contribute to global warming and climate change (IPCC). Renewable energy is extremely important to ensure future energy security, stability, and prosperity. In addition, a switch to renewable energy can reduce global warming emissions. Being nearly inexhaustible, solar energy can also help stabilize energy prices, along with providing many other economic benefits [7]. Solar energy has the greatest potential of any almost-continuous energy source [8].

Sunlight covers the electromagnetic spectrum ranging from ultraviolet, visible light, and infrared (heat). All may be utilized directly or indirectly through conversion into electricity [9]. According to 
the National Renewable Energy Laboratory (NREL), the technical potential of photovoltaic cells and concentrated solar power (CSP) is as much as $200,000 \mathrm{GW}$ in the United States alone; this is enough to generate about 400,000 TWh of energy annually [8]. Despite high initial investment costs, a solar home system (SHS) is an emerging alternative energy source for many rural areas in the developing world. Simplicity and emission-free conditions are key attractions of SHSs. Moreover, the cost of solar systems has declined significantly, while their efficiency has increased greatly with advances in technology. For example, the total module cost decreased from around $\$ 1.30$ per watt in 2011 to around $\$ 0.50$ per watt in 2014 (almost 60\%) [10]. Likewise, solar cell efficiency has improved constantly (e.g., from 11.4 to $17 \%$ using perovskite [8]). Figure 1 shows the worldwide growth of solar systems since 2006. However, in developed countries, almost $100 \%$ of the population has access to grid electricity. Large-scale solar energy usage is found mainly in developed countries. In contrast, in the developing world, small-scale (40 to 100 Watt) domestic solar systems are more prominent. About 1.1 billion people, concentrated in Africa and Asia, are known to live without access to electricity [11].

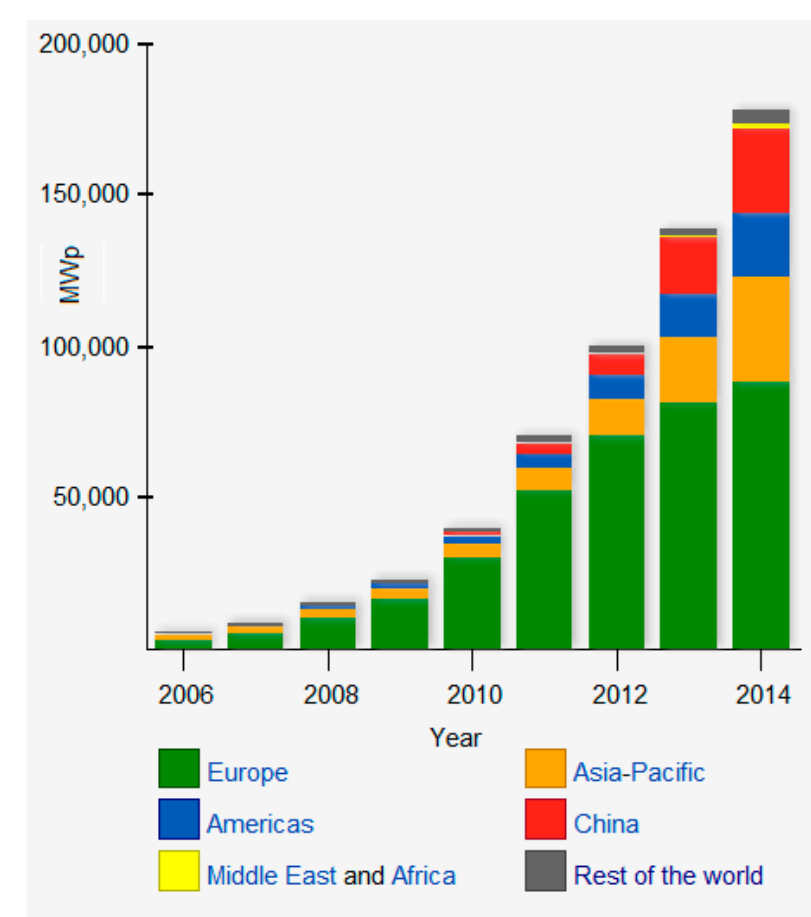

Figure 1. Global growth of solar energy [12].

The SHS program has been very successful (Figure 2) in Bangladesh, where SHS projects are managed by a government financial institution (Infrastructure Development Company Limited (IDCOL)) [13]. The Bangladeshi SHS model could be replicated and launched in other parts of the world. This survey study conducted in rural areas of Tangail district focused on the impacts of SHSs on rural population lives in Bangladesh. Mondal and Klein [14] and Khan and Azad [15] also conducted their study on SHS social impacts of rural people near Dhaka city in October 2004 to January 2005 and 2013, respectively. However, over the years, the basic conditions of SHS technology (e.g., package price, load demands, socio-economic condition, and awareness) have been changed. Evaluation of the social impacts of SHSs on the lives of rural people who are not connected to electricity grids can be assessed after the installation of the SHSs and may help policymakers create SHS policies to improve the living standards of off-grid rural populations world-wide. 


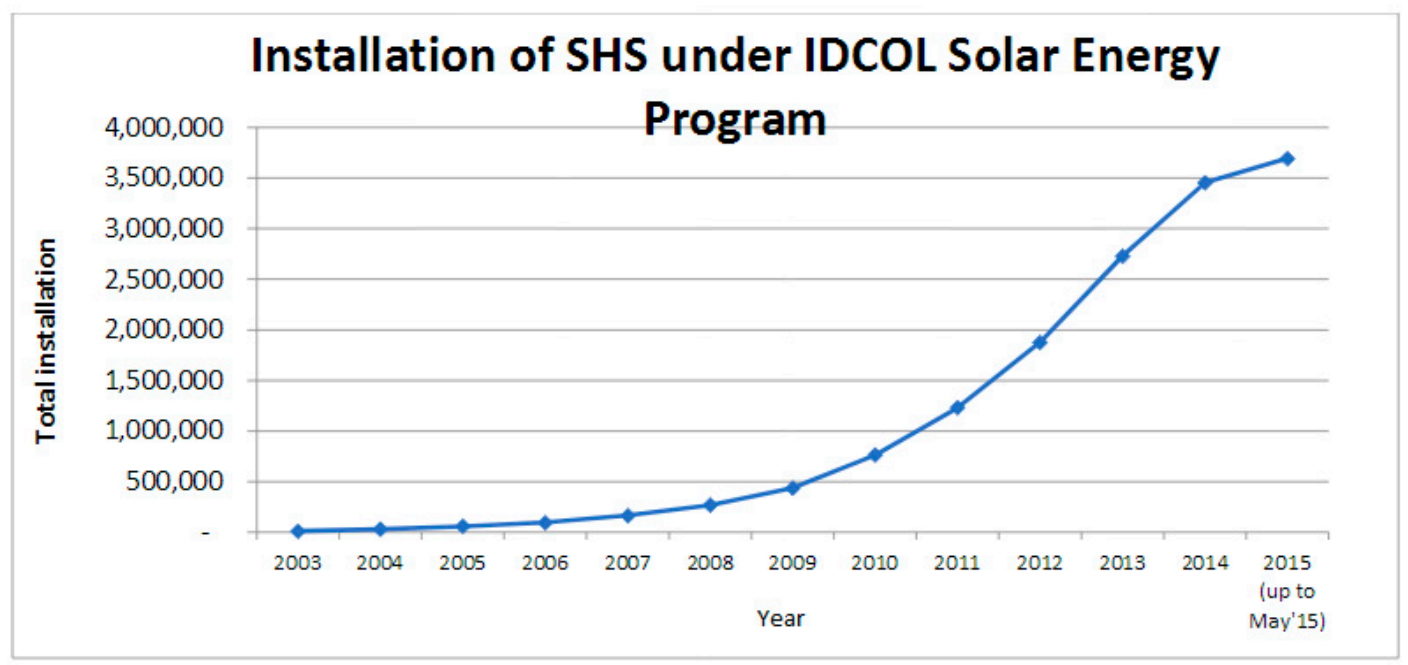

Figure 2. Annual SHS installations in Bangladesh [16].

\section{Operation Principle of an SHS}

Solar panels are made up of many individual solar energy collectors called solar or photovoltaic (PV) cells that convert sunlight energy directly into electricity due to the photovoltaic effect [17]. Solar cells are usually wafer-based crystalline silicon cells or thin-film cells on cadmium telluride or silicon substrate [18]. The cells are very thin (about $1 / 100$ th of an inch), usually 3 to 4 square inches (around 20 to $25 \mathrm{~cm}^{2}$ ), and have a standard lifetime of 20-30 years [19].

An SHS includes a solar panel, one or more batteries, a charge regulator or controller, an inverter to convert direct current (DC) to alternating current (AC) for grid-compatible AC appliances, cables, and switches for safety (Figure 3). An SHS usually operates at a rated voltage of $12 \mathrm{~V}$ direct current (DC) to provide power for low power DC appliances such as lights, radios, and small TVs for about three to five hours a day [20]. The PV module is usually placed on the rooftop of a house at an angle to collect maximum sunlight. The battery of the SHS should typically have a storage capacity of 3 days in the event of cloudy days.

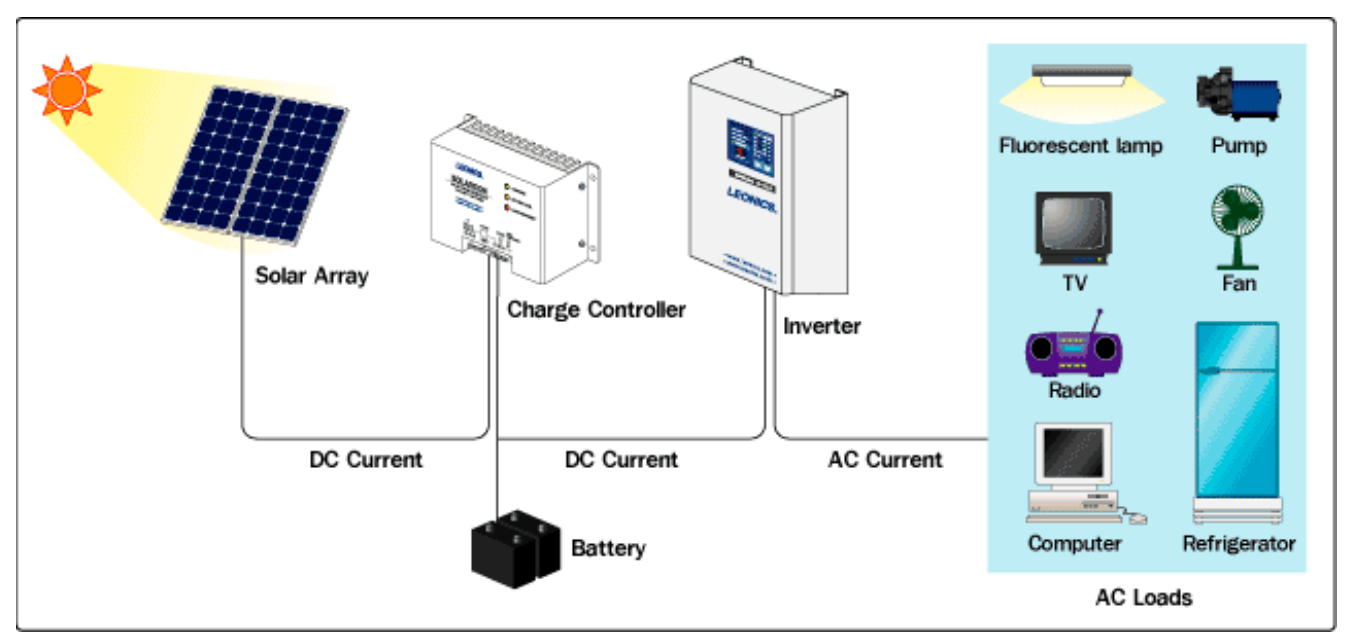

Figure 3. Typical solar home system [21]. 


\section{Site Area and Household Characteristics}

This case study was carried out at Ghatail Upazila, which is located in the Tangail district, Bangladesh from April to December, 2014 (Figure 4). This area was chosen as many parts of this area are not connected to the national grid. The study area selected in this study thus represents ones with true rural characteristics of Bangladesh away from urban facilities. A total of 119 SHS users were surveyed, including household (98 users) and small businesses ( 21 users), by the face-to-face questioner method. The survey contained both closed-ended questions (i.e., respondents were given a list of predetermined responses from which to choose their answer) and open-ended questions (respondents were asked to answer in their own words). Data were collected on the basis of five-point Likert scale, ranging from $1=$ strongly disagree to $5=$ strongly agree. Both the open-ended and close-ended questions were included in the questionnaire. Questionnaire was carefully developed and tested before it was finalized to find out customer satisfaction of the SHS customers. Here Servqual Model is used to assess the gap between the expectations and perceptions of the customers. The data analysis involved quantitative and qualitative methods (numerical and descriptive). Qualitative data were analyzed based on content analysis while quantitative data were analyzed using descriptive and inferential statistics.

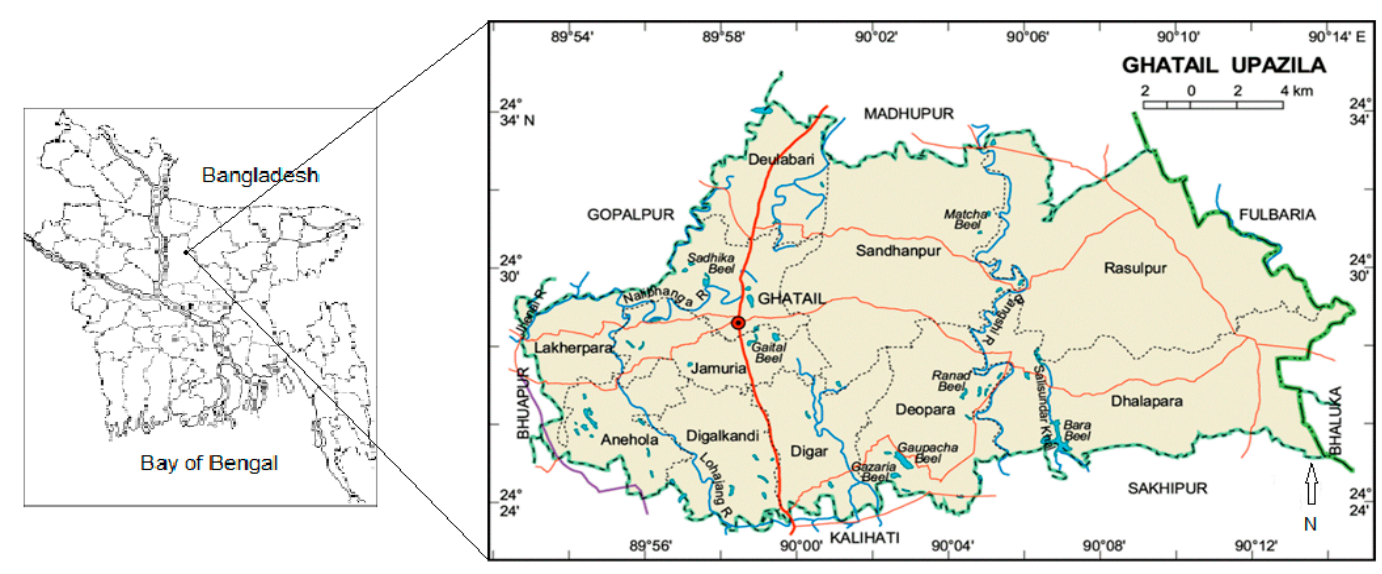

Figure 4. Map of the study location [22].

Agriculture is the main occupation (42.9\% of respondents) in the study area. About $22 \%$ of the respondents engaged in some business activities (Figure $5 \mathrm{a}$ ). About $49 \%$ and $41 \%$ of SHS households had monthly incomes of 65 to 130 USD (5001 to 10,000 Bangladeshi Taka (BDT)) and 130 to 190 USD (10,001 to 15,000 BDT), respectively (Figure 5b). Of the available 30, 40, 50, 60, 75, 80, and 120 Wp SHSs; 40 to $85 \mathrm{Wp}$ SHSs are the most common in rural areas, with the $50 \mathrm{Wp}$ SHS the most common SHS used by households [23]. Typical operating load of a $50 \mathrm{Wp}$ SHS is 3-5 LED bulbs and a $14^{\prime \prime}$ or $17^{\prime \prime}$ black \& white TV. There are different credit and pricing options for purchasing SHS unit, e.g., cash, one, two, or three-year installment plans. For example, the cost of a $50 \mathrm{Wp}$ system is around 19,500 or 27,100 BDT (250 or 346 USD) with cash or a three-year microloan facility, respectively [24]. The SHS cost (250 USD) in Bangladesh represents a large fraction (7.8\%) of the purchasing power parity (PPP) GDP per capita (3175 USD) of that country. In contrast, in the USA (PPP GDP per capita 54,000 USD), it is only $0.46 \%$ [25]. The estimated medium income of the villagers is around 1500 USD.year ${ }^{-1}$ at the March 2016 exchange rate. 


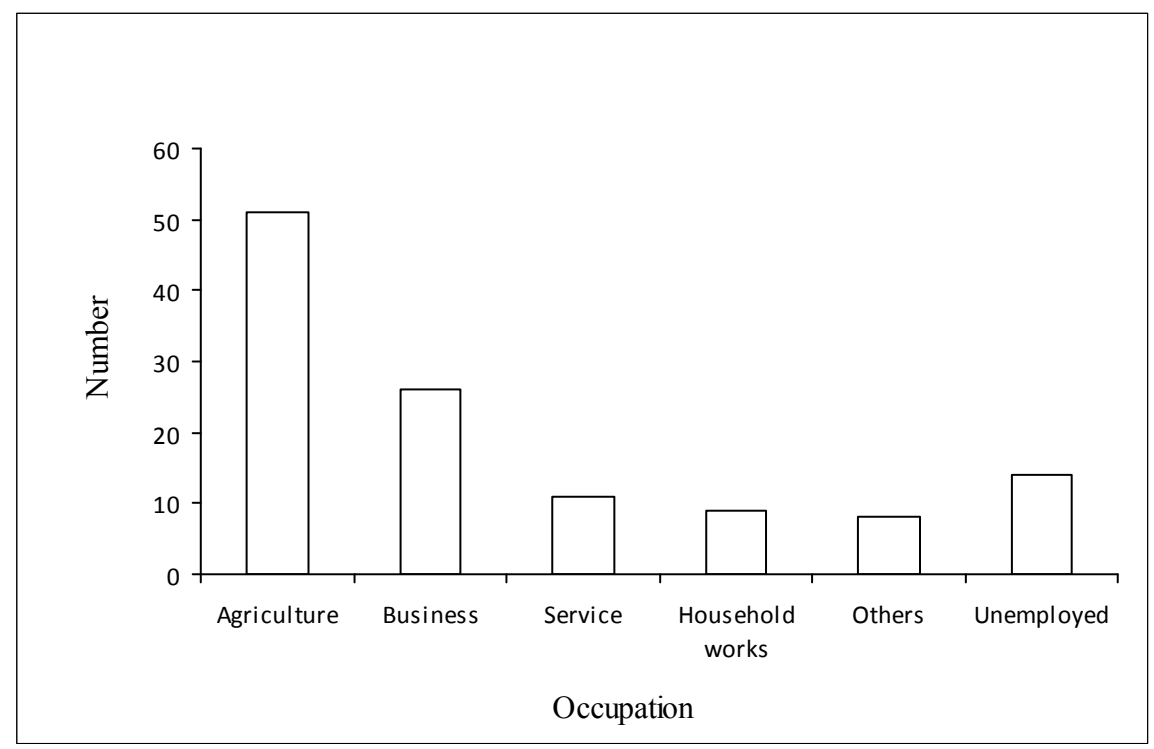

(a)

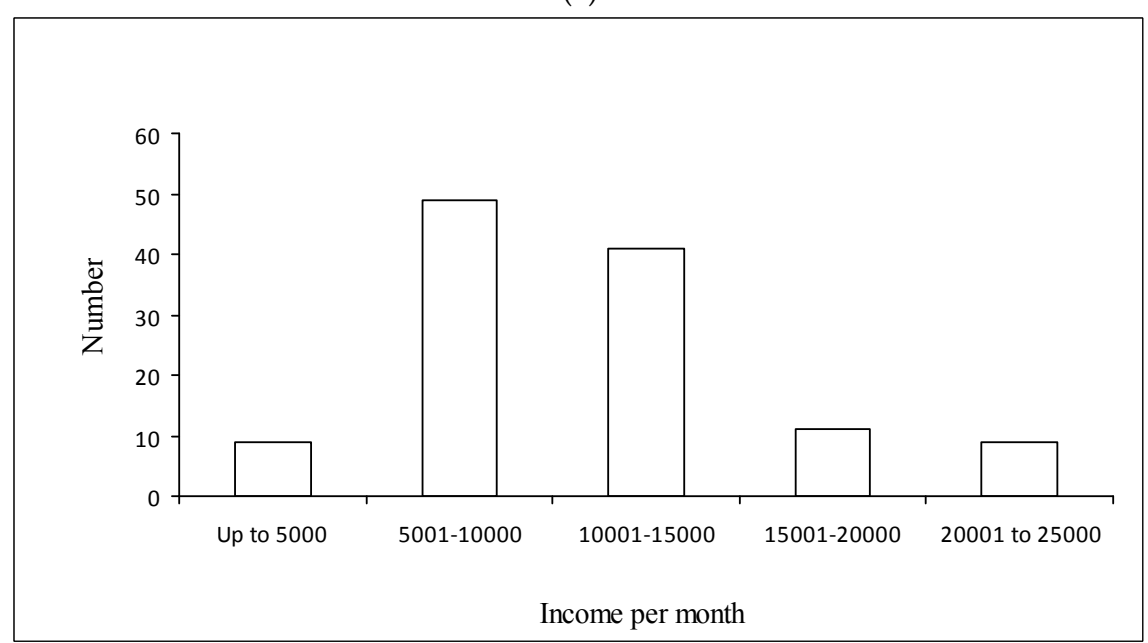

(b)

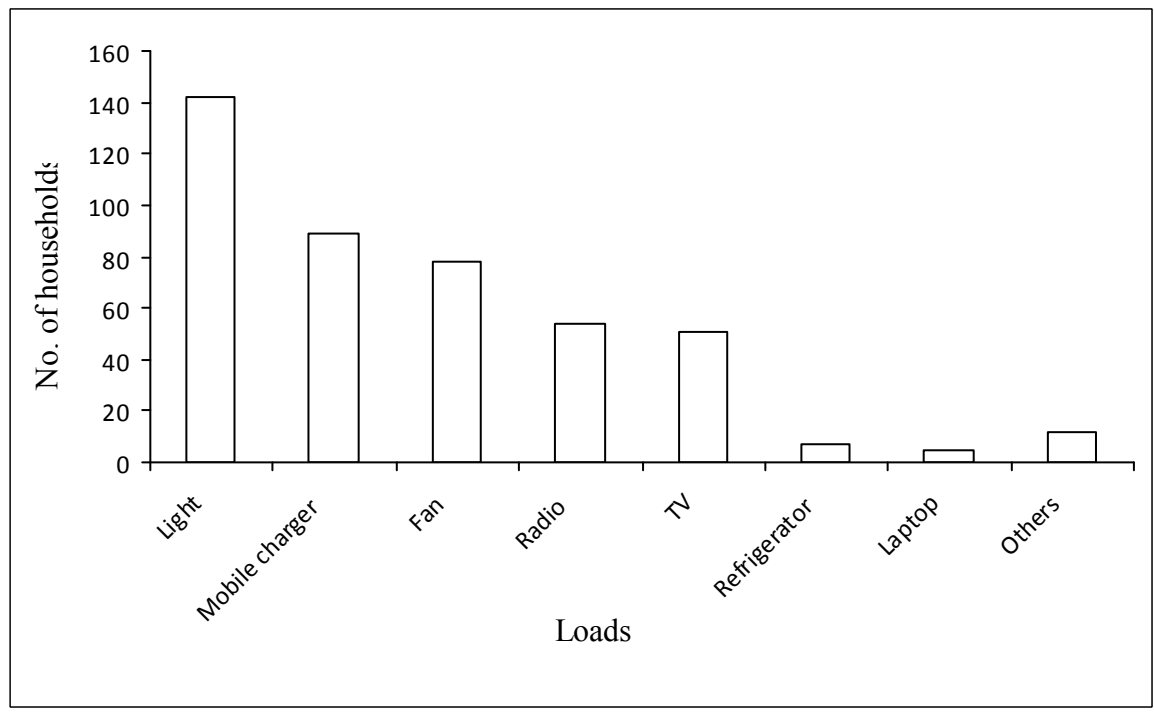

(c)

Figure 5. Cont. 


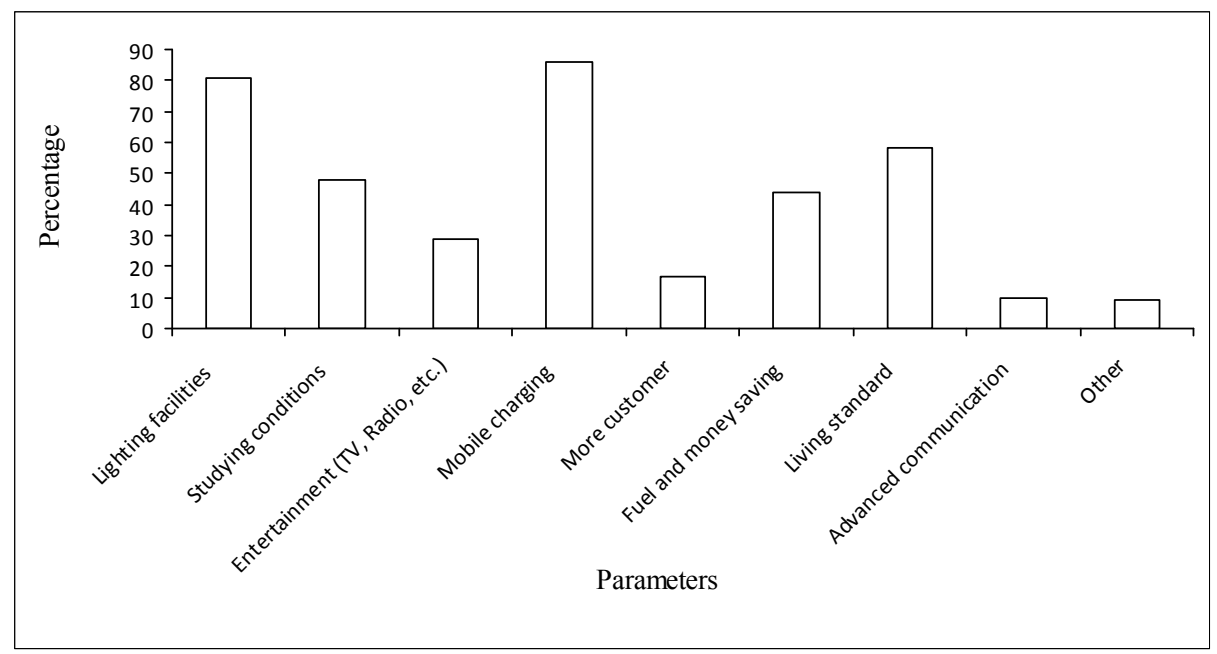

(d)

Figure 5. (a) Occupation of the responders; (b) Household income per month in BDT; (c) Load use data by households; (d) Impacts of SHS on improving the quality of life.

The Infrastructure Development Company Limited (IDCOL) supports the distribution of SHSs in the remote areas where electrification through gird expansion is challenging and costly through 47 Partner Organizations (POs), namely experienced non-governmental organizations (NGOs) such as Grameen Shakti (GS), the Bangladesh Rural Advancement Committee (BRAC), Rural Services Foundation (RSF), and SolarEn [26]. A number of smaller NGOs and private enterprises also participate in SHS distribution in Bangladesh. However, IDCOL provides refinancing facilities to the POs and channels grants to reduce the cost of the systems to make them more affordable to rural customers. According to the collected data, about $82 \%$ households microfinanced their SHS by monthly installments, mostly over a period of 3 years. For a 3-year microloan plan, a minimum 10 to $15 \%$ down payment was required and the remaining amount was required to be repaid within (maximum) 36 months at a $\sim 12 \%$ (flat rate) service charge per year, equivalent to $>20 \%$ compound interest per year. This type of policy can also be implemented in other parts of the developing world to enable poor people to have easy SHS access.

\section{Loads}

Use of various types of electronic devices and appliances by people living in rural areas is increasing. Figure $5 \mathrm{c}$ shows the range of electronic loads used in the SHS study area. Results from the survey revealed that electric lights were the most dominant application, followed by mobile chargers, fans, radios, TVs, refrigerators, and laptops. Radios were most frequently used in grocery stores, where rural people usually spend their leisure time. Almost all tea stalls had a small TV set to attract customers. Nearly $40 \%$ of the surveyed families had at least one black and white TV in their homes. Refrigerators were not yet common (only present in seven households). Few families possessed laptops; these were mostly gifted from family members who live abroad. However, use of electricity in rural areas is increasing in line with the growing aspirations of families. This change in lifestyle was facilitated by installation of SHSs.

\section{Impacts of SHSs}

An SHS has both direct and indirect impacts on users, with some impacts permanent in nature. Access to SHS electricity enhances the general quality of life of its users. Activities of daily living (ADL) like studying and working under light, watching TV programs, charging electronic devices (e.g., mobile phones, laptop, etc.) are frequently undertaken by people who have an SHS unit in their 
household, thus promoting household welfare by providing a better quality of life or more productivity. Figure $5 \mathrm{~d}$ lists the positive impacts of SHS on quality of life in the studied area.

\subsection{Lighting Facilities}

Lighting is the most common SHS application, and most SHS packages include LED lights. LED lighting provides a step forward in quality and convenience. Solar lighting allows rural families to extend their workday into the evening hours. Due to extended study and household work hours, convenience, safety, cleanness, and brightness, lighting is considered to be the most important benefit of SHSs. Approximately $64 \%(n=77)$ of householders responded that lighting was the main purpose they installed an SHS. Poisonings, fires, and explosions are well-documented kerosene hazards [27]. In contrast to kerosene lamps, solar lights (or lanterns) are free of toxic emissions. Moreover, use of an SHS reduces the time spent maintaining and refueling kerosene lamps. In rural areas, purchasing and transporting kerosene fuel is often both difficult and expensive. Brighter SHS lights are also a vast improvement on the poorer light provided by kerosene lamps. Due to lighting facilities, students had more time to study, and women no longer depended solely on sunlight to complete their household chores. Lighting also benefited other household activities, such as sewing by women, social gatherings after dark, and so on. Solar electricity also helped local enterprises like small shops and village markets to operate during the evening, and relieved their reliance on grid supply, which is very unreliable, especially in rural areas of Bangladesh.

\subsection{Information Facilities}

Although lighting was the most popular application, access to various entertainment and communication facilities provided a strong SHS incentive. SHS increased the opportunity to access information through watching TV and/or listening to radio broadcast information, and provided better communication opportunities via mobile phones and/or the Internet. Due to the high level of illiteracy prevalent in rural areas, radio and television are the most effective means of reaching rural inhabitants, and thus play an important role in socio-economic development [28]. The Internet has now made it possible to obtain and share information, e.g., on education and health issues with local and international organizations such as NGOs, farmers' organizations, and women' s organizations. International development agencies and national development partners are already experimenting with new information technologies and electronic communication networks for rural development. Such information tools can be very influential at spreading important messages about new agricultural production ideas and techniques as well as health, nutrition, family planning, and other social and cultural issues. Besides personal communication, mobile communication has several economic and social benefits; it can enhance entrepreneurship, reduce information asymmetries and market inefficiencies, and facilitate better transport. Access to such facilities can bring about changes in the lifestyle of rural people. Rather than spending time talking to each other (socializing), the participants of our study preferred to watch TV shows to be up-to-date on current national and global affairs. Rural people gathered in tea stalls or shops in the market place to watch a special program, movie, or match together. Enjoying TV entertainment shows helped them to relax after a day's farming and other activities. Rechargeable lead-acid batteries usually used to power TV sets need to be transported over several kilometers for recharging in many cases. An SHS requires only sunlight and will last up to 20 years with minimal servicing.

\subsection{Health and Environment}

SHSs can have significant health and environmental benefits in rural areas. Because an SHS has a minimal installed carbon footprint and solar energy is in almost inexhaustible supply in the foreseeable future, SHSs are likely to have more positive environmental impacts than fossil and biomass fuels. An SHS can replace kerosene lamps, which emit substantial amounts of fine particulates, carbon monoxide $(\mathrm{CO})$, nitric oxides $\left(\mathrm{NO}_{\mathrm{x}}\right)$, and sulfur dioxide $\left(\mathrm{SO}_{2}\right)$, all of which adversely effects 
indoor air quality [29]. These pollutants may cause impair lung function and increase infectious illness (including tuberculosis), asthma, and cancer risks [21]. SHSs have been found to result in less pollution and reduce the inconvenience associated with use of kerosene lamps. Among respondents, only $10 \%$ occasionally still used kerosene lamps for lighting whenever needed. Use of SHS also helps to decrease local air pollution. There was a decrease in local pollution levels resulting from the reduced use of kerosene lamps and small diesel generators [30]. Moreover, SHS generates electricity with no direct carbon dioxide $\left(\mathrm{CO}_{2}\right)$ emissions. The net carbon emission offset is estimated to be approximately 6 tons of $\mathrm{CO}_{2}$ over the 20-year life of one PV system [31]. Kerosene, diesel fuel, or gasoline stored for lamps and small generators are potential safety hazards, and significant numbers of burn injuries caused by kerosene lamps are reported around the world. In the Philippines, there have been numerous reports of fire deaths caused by kerosene lamps [32].

\subsection{Economic Benefits}

SHSs were considered economically beneficial by $71 \%$ of the householders. After SHS installation, maintenance costs are projected to be minimal over 25 years. SHS householders who used solar-powered LED lights avoided buying kerosene every month for kerosene lamps. Usually, if the kerosene price increased, it resulted in reduced consumption to avoid an increase in monthly kerosene expenditure. An SHS also saves its users time, money, and energy for purchasing and transporting kerosene from markets. Moreover, due to efficient lighting, householders were able to pursue commercial activities like sewing and handicrafts. Four sewing machines were recently bought by four women with the help of loan by a NGO, which together with an SHS, will allow them to earn extra money by sewing in the evening hours using solar light. Owners of tea stalls and local shops reported longer evening business hours and increased profits since the installation of an SHS. This profit money could be further invested for business expansion. Grocery shop owners who were using kerosene lamps for their business extended their working activities by around 2 hours as a result of introduction of the SHS.

\section{Comparison with Previous Studies}

To our knowledge, few case studies of SHSs in rural areas have been performed. The impacts of solar lanterns have been rigorously reviewed with respect to the performance of children attending primary and secondary schools in a geographically challenged area in northern Bangladesh (river island areas or Chars) [33]. The object was to improve the children's study environment at night. The study period was from April 2013 to October 2014, and 800 d. light solar lantern units were distributed. The solar lanterns units were procured using social business funds (Daiwa Securities) and generous donations from two NGOs (BRAC and Gono Unnayan Kendra). The minimum cost for a $10 \mathrm{~W}$ solar panel with 2/3 LED lights is about 9800 taka (or 125 USD). The Chars lack grid electricity and are subject to seasonal flooding. During seasonal flooding, severe land erosion occurs, forcing Char inhabitants to migrate to higher ground. This requires the fixed SHS to be moved, which is often difficult due to lack of transportation infrastructure. Consequently, the Bangladeshi Rural Electrification Board (REB) does not have any plan to electrify the Chars.

Of the 2795 children in 4 th to 8 th grades in 28 schools in eight Chars, 1292 children were initially selected from 17 schools in two Chars (i.e., Gaibandha and Kurigram) that received very limited SHS service from an NGO. Of the 1292 selected children, 911 did not have access to SHS at the start of the survey (April-May 2013). Eligible students were selected based on a school attendance of at least $80 \%$ (June 2013). A randomized control trial (RCT) was used to assess solar lantern effectiveness.

The main findings (of 852 households ( 436 households without solar lanterns as controls\}) and 911 students) were that the initial benefits faded over time, e.g., children's exam grades did not improve. On the other hand, there was a reduction in biomass energy consumption (and indoor air pollution) in households equipped with solar lanterns. The household willingness to pay for solar lanterns increased from $\sim 0 \%$ (in the 1 st month) to near $100 \%$ after 12 months during the study period. The medium 
expenditure for food of the 436 households without solar lanterns was 58,600 $\pm 22,750$ BDT per year, which represents $\sim 77 \%$ of total expenditure (970 USD).

Similar SHS case studies have been carried out in the sub-Saharan country of Kenya [34,35]. Sharma [36] discussed the benefits of decentralized energy developments in rural India to women with regard to reducing the household chore burden, e.g., collecting biomass fuel. Women were also trained by an NGO to install, maintain, and repair SHSs. Previous studies on SHSs, however, have lacked rigor due to small sample sizes, as discussed by Kudo et al. [26]. Detailed discussion of SHSs outside Bangladesh is beyond the scope of this study.

Note that the marketing of SHS in remote areas is challenging due to technical and financial reasons. Many poor households are reluctant to purchase a solar unit at their own expenses. Hence, a number of favorable financial options (e.g., subsidy on SHS purchase/maintenance, reasonable interest rates, and acceptable loan duration), if offered, would be useful to accelerate SHS adoption among poor people. The self-selection of the SHS program by client should nonetheless be affected by the price of the particular module, credit availability, the cost of alternatives to electricity (e.g., kerosene), etc. [37]. Although the subsidy on SHS has been declining over time (about $25 \%$ in 2004 to about 10\% in 2012) in Bangladesh, the overall demand of solar panel has increased by $2 \%$ with the declining unit price of $10 \%$ [7].

\section{Constraints}

Most of the SHS users were satisfied overall with the SHS itself. However, lack of technical expertise and poor after-sales service were the most pronounced SHS shortcomings according to the respondents. A waiting time of a day or two or even more was often required to fix an SHS problem. Moreover, battery replacement costs after six or seven years represented a significant financial burden to the study participants. The price of an SHS was considered to be another main obstacle for its usage. Many of the users (37\%) stated that they faced difficulties in paying the initial down-payment and meeting monthly payments. A significant cost constraint for poor users was that the minimum monthly payments involved relatively large amounts (over 300 BDT or 4 USD for a $10 \mathrm{Wp}$ SHS) at a time when kerosene could be purchased in smaller quantities at lower cost on a daily basis and if necessary, on credit. About $8 \%$ of the surveyed solar panels were not producing at optimal capacity due to many factors, e.g., shadowed by trees. Moreover, solar panels gradually become damaged by ultraviolet radiation, rain, dirt, temperature fluctuations, hail, and wind [38]. It was also noticed that some of the users $(15 \%)$ did not regularly clean the surfaces of the panels. As a result, a thick layer of dust accumulated on the panels, causing a drop in power output. About $21 \%$ of the respondents complained that battery charging was not adequate to meet their demands. About $19 \%$ of the users noticed battery over-heating towards the end of the battery life. About $23 \%$ of users experienced blackening on either one or both ends of the fluorescent lamps. During the rainy season or in foggy weather, the battery could not be fully charged and users had to limit their consumption. Additionally, many SHS users simply dumped the worn-out or faulty SHS components, which is a matter of great environmental concern, as this will likely increase as the number of SHS users increases.

\section{Conclusions}

SHS can satisfy basic energy needs (i.e., lighting), especially in off-grid rural areas in Bangladesh. SHS has profound and far-reaching economic, socio-cultural, and demographic impacts on life and living of the rural people in Bangladesh. Most of the respondents are found satisfied with their SHS. However, cheaper SHSs and reduced down-payment options combined with more flexible microloan facilities should be introduced to attract poorer target groups to SHSs. Poverty reducing impacts could also be achieved by promoting larger-capacity SHS that can be used for income-generating activities. Most of the users did not have the necessary technical knowledge to maintain their SHS or obtain optimal benefits. Basic training (e.g., fixing minor technical problems, cleaning the panel) of users and good support service would ensure the continued functionality of an SHS. Because an SHS is 
an interlocked system (i.e., if any one of the devices components is damaged, the system does not work), after-sales service is very important. If after-sales service is poor, this could have an adverse effect on growth of the SHS market. Skilled technicians are another significant obstacle for after-sales services. Due to the presence of numerous manufacturers (local and foreign), standard component testing is highly recommended. Maintenance of a standard quality will increase the lifespan of SHSs and also make SHSs more feasible for use in the future.

Acknowledgments: This study was supported by a grant from the National Research Foundation of Korea (NRF) funded by the Ministry of Education, Science, and Technology (MEST) (No. 2006-0093848).

Author Contributions: Ehsanul Kabir, Ki-Hyun Kim and Jan E. Szulejko designed experiments. Ehsanul Kabir performed the experiments. Ehsanul Kabir, Ki-Hyun Kim, and Jan E. Szulejko analyzed the data and organized the paper.

Conflicts of Interest: The authors declare no conflict of interest.

\section{References}

1. Laufer, D.; Schäfer, M. The implementation of Solar Home Systems as a poverty reduction strategy-A case study in Sri Lanka. Energy Sustain. Dev. 2011, 15, 330-336. [CrossRef]

2. World Bank. Access to Electricity (\% of Population). Available online: http://data.worldbank.org/indicator/ EG.ELC.ACCS.ZS (accessed on 9 March 2017).

3. Mondal, M.A.H. Economic viability of solar home systems: Case study of Bangladesh. Renew. Energy 2010, 35, 1125-1129. [CrossRef]

4. Government of Bangladesh. Bangladesh's Power Sector at a Glance (May 2015). Available online: http://www. powercell.gov.bd/site/page/d730f98d-8912--47a2--8a35--382c4935eddc (accessed on 21 September 2017).

5. Burt, E.; Peter, O.; Susan, B. Scientific Evidence of Health Effects from Coal Use in Energy Generation; University of Illinois at Chicago: Chicago, IL, USA, 2013. Available online: https:/ / noharm-uscanada.org/documents/ scientific-evidence-health-effects-coal-use-energy-generation (accessed on 1 May 2017).

6. Kharecha, P.; Hansen, J. Coal and Gas Are Far More Harmful than Nuclear Power. Available online: http://www.giss.nasa.gov/research/briefs/kharecha_02/ (accessed on 15 February 2017).

7. Samad, H.A.; Khandker, S.R.; Asaduzzaman, M.; Yunus, M. The Benefits of Solar Home Systems: An Analysis from Bangladesh; Policy Research Working Paper; No. 6724; World Bank: Washington, DC, USA, 2013. Available online: https:/ /openknowledge.worldbank.org/handle/10986/16939 (accessed on 21 September 2017).

8. National Renewable Energy Laboratory. U.S. Renewable Energy Technical Potentials: A GIS-Based Analysis; National Renewable Energy Laboratory: Golden, CO, USA, 2012. Available online: www.nrel.gov/docs/ fy12osti/51946.pdf (accessed on 9 March 2017).

9. Khan, S.; Towfiq, R.; Hossain, S. A brief study of the prospect of solar energy in generation of electricity in Bangladesh. JRSE 2012, 1-8. Available online: www.cyberjournals.com/Papers/Jun2012/02.pdf (accessed on 21 January 2017).

10. Renew Economy. Why Solar Costs Will Fall Another $40 \%$ in Just Two Years. Available online: http: / / reneweconomy.com.au/2015/why-solar-costs-will-fall-another-40-in-just-two-years-21235 (accessed on 9 March 2017).

11. World Bank. Where Does the World Stand in Reaching Sustainable Energy Objective? Available online: http://www.worldbank.org/en/news/feature/2015/05/18/where-does-the-world-stand-in-reachingsustainable-energy-objectives (accessed on 5 March 2017).

12. International Energy Agency. Photovoltaic Power Systems Programme. Available online: http://www.ieapvps.org/index.php?id=32 (accessed on 25 May 2017).

13. Bangladesh Power Development Board (BPDB). Annual Report 2012-2013; Bangladesh Power Development Board (BPDB): Dhaka, Bangladesh, 2014. Available online: http://www.bpdb.gov.bd/bpdb/index.php? option=com_content\&view=article\&id=75\&Itemid $=80$ (accessed on 29 February 2017).

14. Mondal, A.H.; Klein, D. Impacts of solar home systems on social development in rural Bangladesh. Energy Sustain. Dev. 2011, 15, 17-20. [CrossRef]

15. Khan, S.A.; Azad, A.K.M.A.M. Social Impact of Solar Home System in Rural Bangladesh: A Case Study of Rural Zone. Energy Environ. 2014, 1, 5-22. [CrossRef] 
16. Infrastructure Development Company Limited (IDCOL). Request for Expression of Interest (REoI) E Terms of Reference (ToR): Selection of Software Development Firm for Developing Enterprise Resource Planning (ERP) for Automation of IDCOL Solar Home System Program; Infrastructure Development Company Limited (IDCOL): Dhaka, Banglades, 2016. Available online: idcol.org/notice/218305f4847e3e4f3e90c8918a377a29.pdf (accessed on 5 March 2017).

17. Li, S.; Haskew, T.A.; Li, D.; Hu, F. Integrating photovoltaic and power converter characteristics for energy extraction study of solar PV systems. Renew. Energy 2011, 36, 3238-3245. [CrossRef]

18. An, B.I.; Kim, G.B. Development of structured hybrid illumination system and optimum illumination condition selection for detection of surface defects on silicon wafer in solar cell. J. Korean Soc. Mech. Eng. A 2012, 36, 336-337. [CrossRef]

19. Neuhaus, D.H.; Münzer, A. Industrial Silicon Wafer Solar Cells. Adv. OptoElectron. 2007, $2007,24521$. [CrossRef]

20. Phadke, A.; Jacobson, A.; Park, W.Y.; Lee, G.R.; Alstone, P.; Khare, A. Powering a Home with Just 25 Watts of Solar PV: Super-Efficient Appliances Can Enable Expanded Off-Grid Energy Service Using Small Solar Power Systems; Lawrence Berkeley National Laboratory: Berkeley, CA, USA, 2015; pp. 234-256.

21. Leonics. Solar Home System. 2017. Available online: http://www.leonics.com/system/solar_photovoltaic/ solar_home_system/solar_home_system_en.php (accessed on 2 May 2017).

22. Maps of Bangladesh. Political Map of Ghatail Upazila-Tangail District. 2017. Available online: http:/ / mapsof-bangladesh.blogspot.com/2010/12/political-map-of-ghatail-upazila.html (accessed on 2 May 2017).

23. Urmee, T.; Harries, D. Determinants of the success and sustainability of Bangladesh's SHS program. J. Renew. Energy 2011, 36, 2822-2830. [CrossRef]

24. GS Solar Home System Program, Grameen Shakti, Bangladesh. 2016. Available online: www.gshakti.org (accessed on 15 February 2017).

25. Central Intelligence Agency. The World Fact book. Available online: https://www.cia.gov/library/ publications/the-world-factbook (accessed on 25 December 2016).

26. Infrastructure Development Company Limited. Available online: http://www.idcol.org (accessed on 22 February 2017).

27. Lam, N.L.; Smith, K.R.; Gauthier, A.; Bates, M.N. Kerosene: A review of household uses and their hazards in low- and middle-income countries. J. Toxicol. Environ. Health B Crit. Rev. 2012, 15, 396-432. [CrossRef] [PubMed]

28. Mala, K.; Schlapfer, A.; Pryor, T. Better or worse? The role of solar photovoltaic (PV) systems in sustainable development: Case studies of remote atoll communities in Kiribati. Renew. Energy 2009, 34, 358-361. [CrossRef]

29. Epstein, M.B.; Bates, M.N.; Arora, N.K.; Balakrishnan, K.; Jack, D.W.; Smith, K.R. Household fuels, low birth weight, and neonatal death in India: The separate impacts of biomass, kerosene, and coal. Int. J. Hyg. Environ. Health 2013, 216, 523-532. [CrossRef] [PubMed]

30. World Health Organization. Household Air Pollution, Climate and Health. Available online: http:/ / www. who.int/entity/sustainable-development/LR-HAP-27May2016.pdf?ua=1 (accessed on 20 September 2017).

31. Mukherjee, S.; Ghosh, P.B. Estimation of carbon credit and direct carbon footprint by solar photovoltaic cells in West Bengal, India. Int. J. Low-Carbon Technol. 2014, 9, 52-55. [CrossRef]

32. Meier, P. Economic Analysis of Solar Home Systems: A Case Study for the Philippines; Asia Sustainable and Alternative Energy Program (ASTAE); World Bank: Washington, DC, USA, 2003; Available online: http:/ / documents.worldbank.org/curated/en/2003/02/6470416/economic-analysis-solar-home-sysstemscase-study-philippines (accessed on 2 March 2017).

33. Kudo, Y.; Shonchoy, A.S.; Takahashi, K. Impacts of Solar Lanterns in Geographically Challenged Locations: Experimental Evidence from Bangladesh; IDE Discussion Paper No. 502; Institute of Developing Economies: Chiba, Japan, 2015. Available online: https://ideas.repec.org/p/jet/dpaper/dpaper502.html (accessed on 2 March 2017).

34. Opiyo, N. A survey informed PV-based cost-effective electrification options for rural sub-Saharan Africa. Energy Policy 2016, 91, 1-11. [CrossRef]

35. Tong, T.M.; Asare, J.; Rwenyagila, E.R.; Anye, V.; Oyewole, O.K.; Fashina, A.A.; Soboyejo, W.O. A study of factors that influence the adoption of solar powered lanterns in a rural village in Kenya. Perspect. Glob. Dev. Technol. 2015, 14, 448-491. [CrossRef] 
36. Sharma, K. How to energize women: The Indian response. Bull. At. Sci. 2014, 70, 13-16. [CrossRef]

37. Komatsu, S.; Shinji, K.; Ram, M.S.; Partha, P.G. Nonincome factors behind the purchase decisions of solar home systems in rural Bangladesh. Energy Sustain. Dev. 2011, 15, 284-292. [CrossRef]

38. Parida, B.; Iniyan, S.; Goic, R. A review of solar photovoltaic technologies. Renew. Sustain. Energy Rev. 2011, 15, 1625-1636. [CrossRef] 